УДК 373.3.016:811.111(076)

DOI https://doi.org/10.52726/as.pedagogy/2021.2.1

\title{
A. V. BLIASHEVSKA
}

Candidate of Pedagogical Sciences, Assistant Professor, Municipal Higher Educational Institution "Lutsk Pedagogical College" of the Volyn Regional Council, Lutsk, Ukraine

E-mail: ablyashevsjka@lpk.ukr.education

https://orcid.org/0000-0003-3650-932X

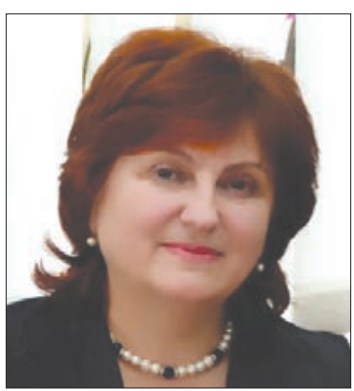

\section{A. FEDORETS}

Instructor of Foreign Languages, Municipal Higher Educational Institution "Lutsk Pedagogical College”

of the Volyn Regional Council, Lutsk, Ukraine

E-mail:mfedoretc@gmail.com

https://orcid.org/0000-0002-2990-4340

\section{IMPLEMENTATION OF THE PROJECT-BASED TECHNOLOGY IN THE BLENDED EDUCATIONAL PROCESS OF TEACHING FOREIGN LANGUAGES IN PEDAGOGICAL HIGHER EDUCATIONAL INSTITUTION IN UKRAINE}

Nowadays the Ukrainian society demands that a specialist of the New Ukrainian School should be prepared to perform their professional functions effectively and fully participate in all spheres of life. This article highlights the topical issues of organizing the educational process in higher educational establishments in Ukraine, namely the formation of general and professional competencies of primary school teachers in accordance with regulations: the law of Ukraine "On Education", professional standard for professions "Primary school teacher in the establishment of general secondary education", "Primary education teacher (with a diploma of junior specialist)". This article presents the analysis of the implementation the project-based technology in the educational process of Pedagogical College as an effective means of students' personal and social development during the classes from different disciplines, students' self-work as well as during the aprobation and undergraduate practice.

The paper provides an overview of the implementation of project-based technology in the process of blended learning a foreign language to achieve the main goals of language learning by future teachers, which involves effective communication in oral and written forms, language use as a means of intercultural communication, the ability to use language as a tool in the cultural dialogue in the modern world. The authors substantiate the didactic potential of interactive teaching methods, in particular the project-based technology, as a component of the system of the formation of the communicative competence in the process of learning English.

The analysis and the generalization of the foreign language instructors experience in Lutsk Pedagogical College are done taking as an example the process of organizing the educational process implementing interdisciplinary practiceoriented long-term project "Lina Kostenko. The poetess above an epoch", which involved the students from the Primary Education department with the additional qualification "English language teacher in primary school". The effectiveness of the project-based technology in the system of formation the general and professional competencies of students of higher educational institutions of Ukraine, as well as communicative competence in particular is proved in this article.

Key words: Project-based technology, innovative technologies, personal and social development, blended learning, future primary-school teacher, higher educational pedagogical establishments.

\section{Introduction}

At the present stage of the development of our society, the special attention is paid to the issue of the formation of the socially active, creative, competent personality, who, unlike a human performer, generates new ideas, make a non-standard decision. According to the new challenges of the changing system of training specialists in higher educational pedagogical establishments, including pedagogical colleges, there is a process to improve methodical systems through the introduction of innovative methods and technologies.

The social order of society is that the specialist of the New Ukrainian School must be prepared to effectively perform their professional functions and full participation in all spheres of life. The content of the work of higher educational 
institutions of pedagogical profile of Ukraine in modern conditions is "comprehensive development, educationand socialization of the individual, capable to live in society and in civilized interaction with nature, striving for self-improvement and lifelong learning, ready for conscious life choice and selfrealization. responsibility, employment and civic activity [Law of Ukraine "On Education"].

In the realities of the global information society, the requirements for the system of professional training of primary school teachers are growing. Approved at the end of 2020, the professional standard for the professions "Primary school teacher in the establishment of general secondary education", "Primary education teacher (with a diploma of junior specialist)" embodies a modern approach to defining the list and description of general and professional teachers' competencies. The list of professional competencies includes: language and communicating; information and digital; psychological; emotional and ethical; pedagogical partnership; inclusive; healthpreserving; design; prognostic; organizational; evaluation and analytical; innovative; reflexive; ability to learn throughout life [Professional Standard].

Professional development standards for staff, teachers, and educators are common in many countries so we take into consideration the experience of the educators from different countries choosing the way to prepare the future teachers to their professional career effectively [Moti Frank and Abigail Barzilai: 39].

Thus, as the analysis of state regulations in modern education shows, the issue of active implementation of innovative technologies, namely the project-based technology, in the system of professional training of educators in general, and primary school teachers in particular, becomes especially important.

The most important place among the innovative technologies used in the pedagogical college, in our opinion, is a project-based technology (PBT). Project-based technology, having nearly a century history of formation and development, considered at the present stage as an innovative technology, because it involves the use of information and communication technologies (ICT), develops the skills of analysis, synthesis, and evaluation, involve different methods of learning: experimental, experiantial, problem-based, etc. A PBT involves the achievements of a didactic purpose through the detailed development of the problem in the process of the researching, investigative, self-reliable, predictive, creative students' activity and it finishes with a real, conscious, practical result, designed in a certain way, provided a constant active interaction between all participants and the integration of various disciplines. We suppose that a project-based technology is the most efficiant model for designing an effective learning environment nowadays when the educational establishment has to implemant blended learning in the pandemic time. The impact of progress in the 21 st century also occurs in the field of education, one of which is technologybased learning. The progress that occurred in the 21 st century is a challenge for teachers as educators, especially in implementing learning by integrating technology [Aini, 2020: 292-304]. Learning must be able to answer the challenges of the 21 st century, one of which is information literacy and ICT (Information and Communication Technology) literacy [Y. Yustina, W. Syafii, R. Vebrianto: 409-415]. Learning must be also designed with multiliteracy pedagogical planning and have various competencies including mastering ICT well for access to information, communication, delivering information to the public, having good critical thinking skills, being able to turn problems into opportunities, having good problem-solving skills [Holloway \& Gouthro: 1-16].

Based on the foregoing, it should be noted that often implementing innovative technologies in general and in particular the PBT in educational process of higher pedagogical education, insufficient attention is paid to personal and social development of students. More in-depth research is required for the usage of the PBT as a means of enhancing personal and social development in the process of future primary-school teachers' preparation. The need for such research is important because, on one hand, the possibilities of the PBT in the process of studying this or that academic discipline, on the other hand, the ability to ensure the autonomy of students in the educational process, their personal and social development.

The purpose of our paper is to analyze the experience in the implementation of PBT in the educational process of Pedagogical College 
as an effective means of students' personal and social development. Our experience displays the implementation of the PBT during the classes of different subjects during the selfwork of students, as well as during the probating and undergraduate practice.

Project-based language teaching in general and in the projects that focus on technology suggests that participating in projects can build decision-making skills, foster independence while also enhancing cooperative work skills, students' creativity, cultivate creative thinking skills, and improve problem-solving skills. Moreover, for the most part, students also generally appear to enjoy projectbased learning especially at the time of pandemic [Gulbahar H. Beckett Tammy Slater : 56].

\section{Analysis of the basic material}

Blended learning is a concept that was developed in the early $1960^{\circ} \mathrm{s}$ and has evolved to different approaches that are widely practiced in educational systems all over the world. Blending is a word that connotes the combination of different components into a whole new structure and consequently formed the basis for the conceptualization of blended learning [Dziuban, C., Graham, C. R., Moskal, P., Norberg, A., \& Sicilia, N.: 1-16]. Blended learning can be described as the integration of the conventional face-to-face learning method with digital or online learning method [Hrastinski, S.: 564-569]. Researchers could not report a generally accepted definition of Blended Learning because it was considered a concept that depends on its application or on circumstances that surround its application. However, the two most widely accepted definitions were given by Graham (2006) and, Garrison and Kanuka (2004) [Garrison, D. R., \& Kanuka, H., (2004) : 95-105]. Graham defines Blended learning as "systems that combine faceto-face instruction with computer-mediated instruction" [Graham, C. R.: 3-21]. Based on this definition, blended learning must be conducted within the four walls of a school since face-toface instruction forms a component of the system. Students and teachers are involved and must then come together in brick-and mortar schools. Similarly, Garrison and Kanuka (2004:96) define blended learning as "the thoughtful integration of classroom face-to-face learning experiences with online learning experiences". It can be gleaned from both definitions that face-to-face learning and online learning are the components of Blended Learning [Mahaye, N.E.: 1-23].

The formation of communicative competence of the subjects of the educational process was investigated by outstanding scholars such as M. Bunakov, F. Buslaev, V. Vodovozov, K. Ushinsky, V. Sukhomlinsky. Some educators as L. Avdonina, M. Baranov, B. Golovin, T. Ladyzhenska, M. Lvov, B. Panov, M. Rybnikova, A. Tekuchov, S. Chavdarov, and J. Stelmakhovych have made a significant contribution to the method of speech development. T. Donchenko, A. Kupalova and other researchers emphasized the communicative orientation of the language learning process. The essence and structure of foreign language professional communicative competence were clarified by A. Andrienko, G. Arkhipova, N. Gez, S. Kozak, O. Pavlenko, N. Prudnikova, Y. Fedorenko, N. Chernova and others.

It is indicated four key areas where more work is needed: communication, personalisation, integrated design, and development of an evidence-base. The research outputs signalled the aspiration for an integrated analytics system transcending the entire student experience, from initial student inquiry right through to qualification completion and into life-long learning [Rienties Bart, Tom Olney, Mark Nichols, Christothea Herodotou: 178-195].

Nowadays it is proposed three delivery modes; blended, distance, and open self-directed mode. It drew on tracking data from 43,000 learners, which revealed overall low completion rates and that the blended mode is more effective in retaining learners than other modes [Friðriksdóttir: 1-22].

Analysis of the modern scientific-methodical papers attests the attention of scholars to the PBT, especially since the experimental implementation of the international educational program "Intel $\mathbb{R}$ Teach for the future" in the pedagogical institutions since 2004 [Dementievska N., Morze N.: 1-14].

The usage of the PBT in the educational process has been studied by E. G. Arvanitopulo, T.I. Gustomjasova, N. M. Dushkova, I.O. Zymnja, A.V. Konisheva, N. F. Korjakovceva, V.V. Kopylova, N.G. Kosheleva, T.M. Pokusaeva, E. S. Polat, T.J. Tambovkìna, D.L. Fried-Booth, S. Haines, T. Hutchinson, R. Ribe, F.L. Stoller, N. Vidal and others. The works of I. Zymna, E. Klimov, J. Samarìn, B. Ananlev have beendevoted 
the exploration of the features of the students' formation in a society. Analysis of the scientific researches shows that the usage of the PBT of project inspires students to learning, reduces the number of absences, pushes them to inter-study and cooperation and in the end increases the level of their academic and social achievements.

The PBT, as S. Ivanova defines, is a system of educational and cognitive techniques, solving specific tasks, a set of methods or operations of the practical or theoretical understanding (cognition) of the reality [S. V. Ivanova, L. S. Pastukhova: 29-49]. The participation in the project is the practice of personal oriented learning in particular student's work based on his/ her free choice, taking into account his/her interests.

Application of the PBT in the process of studing nowadays has several advantages, such as reducing absences, increasing the self-reliance and positive motivation to study [Railsback, J.: 45]. Students' academic success is better here than using other methods of training, because emplementing the PBT the members of project feel greater responsibility for their own way of learning and the results than in the process of traditional methods implementation; have an ability to develop sophisticated skills and abilities, namely: the higher-level thinking skills, problem solving skills, an ability to effective arrangement of the common activities and effective communication; have an access to a wider choice of possibilities, ways and tools for training, thanks to the strategy of the involvement of the people with different experiences and cultural differences into a project-work. For the instructors, on one hand, the benefits of the methods of projects are connected with the growth of their professional skills and obtaining additional opportunities for collaboration with the colleagues and specialists from different branches of science and professional activities, on the other hand, it allows them to build a new relationship with students [Thomas, J.W.: 10]. In addition, many instructors claims, that project-based learning provides the ability to use different methods of teaching students, various instruments and means of training and education [Intel ${ }^{\circledR}$ Teach to the Future].

The goals of the content component formation using the PBT, that must exist as an integrated complex, are as follows: focusing on the updating knowledge that is already existed, the acquisition of new knowledge, developing the ability to select necessary information, forming the ability to construct their knowledge independently, the ability to navigate in the information space, the ability to analyze, synthesize the knowledge of the definite sciences, the ability to examine a phenomenon or process as an integrated facility, actively develop critical thinking, the ability to put forward the hypotheses and to be able to draw conclusions.

To prove the efficiency of the PBT in the educational process of a pedagogical college one can analyze the cast of students, involved in educational projects. A student of pedagogical college is a young man, who is characterized by professional orientation, prepares to perform the functions of a highly qualified teacher in primary school. [Leontiev: 304] Students of pedagogical colleges - is a kind of mobile group, the aim of which is the fixing of a specially organized socio-occupational roles, preparation for the implementation of the important social functions: professional, cultural, socio-political, informative, family, etc. The main directions of students' activity in the pedagogical college is a vocational training, personal growth and selfaffirmation, development of intellectual potential, spiritual enrichment, moral, aesthetic, physical self-improvement.

The development of the first course students solves the problem of the recent students' involvement in the forms of collective life. The behavior of the students differs in high degree of conformism; the freshmen are missing differentiated approach to their roles. Thanks to PBT, the social adaptation of freshmen is speeded that includes: professional adaptation as an adjustment to the nature, content, conditions and organization of educational process, developing the skills of autonomy in educational and scientific activities, and socio-psychological adaptation - adjustment of the individual to the group, relationships in it, developing own style of behavior. Researchers distinguish three forms of adaptation of the freshmen students to the conditions in pedagogical college: 1) formal adaptation, regarding the cognitive-informational adaptation of students to the new surroundings, to the structure of higher education, to the content of training in it, to its requirements, to their duties; 
2) public adaptation - the process of internal integration (unification) of the groups of freshmen students and the integration of the same groups into the student's environment as a whole; 3) didactic adaptation which relates to the students preparation for the new forms and PBTs of teaching in high school establishment [Evtukh M. B., Serdiuk A. P. : 221-226].

Analysed studies highlight that the freshmen do not always acquire knowledge successfully not because they had a weak basement in a secondary school, but because they have not established such personality traits as willingness to learn, the ability to learn independently, to monitor and evaluate themselves, the possess of their own individual peculiarities of cognitive activity, ability to properly distribute your work time for self - training. Accustomed to the daily care and control at their schools, some freshmen are not able to take decisions. They have not developed the skills of self-study and self-education. Many of the freshmen at the beginning of training experience large difficulties, associated with lack of skills for independent educational work, they do not know how to record a lecture, to work with textbooks, to select info in the primary sources, to analyze a large amount of information, clearly express their thoughts.

For the tactics and strategy development that ensures optimum adaptation of the student to the higher educational establishment, it is important to know the vital plans and interests of students, the system's dominant motifs, the level of harassment, their self-esteem, the ability to conscious regulation of their behavior. New conditions of their activity is a qualitatively different system of certain relations, where the forefront is taken by the necessity of independent regulation of their behavior, the presence of those degrees of freedom in organizing their work and life, which until recently they haven't belonged. It is worth to say that the identity of the student develops and changes during the years of studying. The freshmen have new high-quality features: increased self-esteem: "I am a student, not a schoolboy/ schoolgirl"; the richness of the interests to different branches of knowledge; new attitude in personal views on members of the opposite sex; relatively greater personal freedom and independence from their parents. First-year students more likely than students of other courses, participate in multisided social activities. They are more exposed to the influence of the teachers and public organizations.

The second year students have already adapted to the new circumstances. They become more practical in the distribution of time and scholarship, experience greater autonomy and responsibility, think more about the future professional activity etc. The second course is a time of the most intensive curriculum activities. In the life of the sophomores all forms of teaching and educating are intensively included. Students receive general training; their cultural demands and needs are formed. The process of the adaptation to this environment is basically completed. The students of the second course dramatically improves their value-oriented activities in the process of the cognition of their own qualities, learning new knowledge, relationships with elders and peers, they are especially concerned about the score and try to build their behavior based on deliberately chosen or learned criteria and norms. Therefore, the use of PBT in general and especially the approach to analysis and assessment of works, debating during the projects defense, promote personal and professionally significant traits of students' personality [Zelenko A. S.: 42-43].

We share the opinion of N.G. Kosheleva, who believes that the PBT should be systematically applied in the educational process of pedagogical universities, because it provides performance of certain pedagogical and social requirements that puts society before the modern pedagogical higher educational institution - the formation of the subject educational process a clear personality meaningful and significant image of future professional activities in the pedagogic field (Fig. 1) [Kosheleva N.G. : 34 ].

PBT not just provides the above demands, but also creates conditions for planning students individual educational paths, designing which is a real program of their own professional career, mastering the basic principles of the building a successful future, basic principles of pedagogical culture and self-improvement for the further selfrealization, achieving the clear understanding of the sense of the chosen specialty and specialization in educational process of pedagogical college in close relationships with the assessment and accounting the personal characteristics (which 

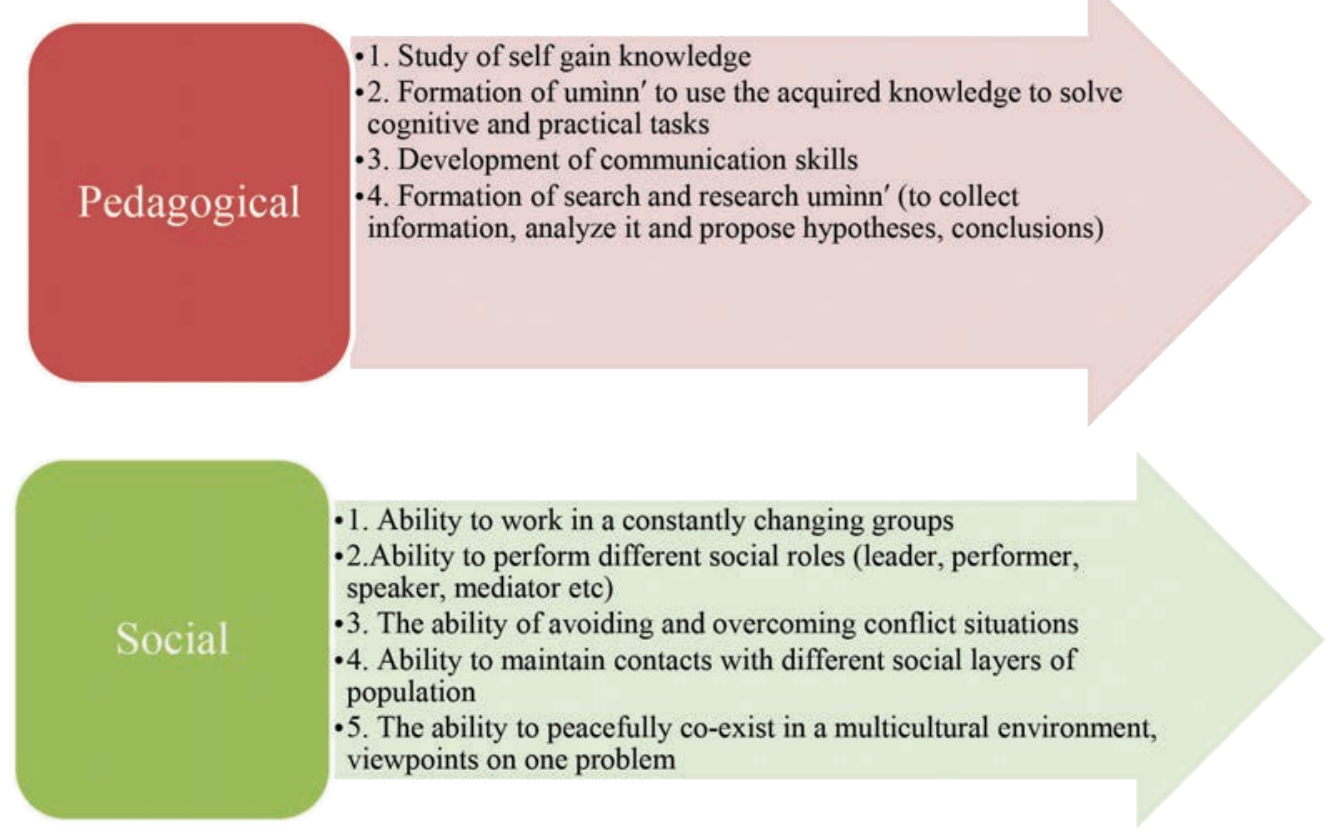

Fig. 1. The list of pedagogical and social requirements underlying the enhanced application of the PBT in practice of modern higher pedagogical establishments

are identified through the needs, interests, values, motives, goals and tasks), as well as inclinations and abilities.

The thirdcourse-beginning of the specialization, strengthening the interest to scientific work as a reflection of the further development and deepening of their professional interests. The need for specialization frequently leads to narrowing the scope of the diverse interests of the personality. There the formation of personality in the basic terms is defined by the factor of specialization. The first real acquaintance with the specialization is taken place in the period of practice. The prospect of the fast graduation from the college forms a clear practical installation on future activities.

Application of the PBT in students blended educational process on the 3 and 4 courses provides mastering by the students the technologies of setting individual vital and professional purposes, obtaining objectives connected with choosing their own career and design successful ways to achieve it, conveying the elements of professional culture, the objective and subjective patterns of the professional formation of the future teachers' personality in pedagogical college. The analysis is presented in Tab. 1.

\section{Results}

In our opinion, the PBT is one of the most effective means of optimizing the process of forming professional and vital competences in higher educational institutions, as it is based on the principles of personal-activity approach to learning, activation of personality, provides for subject-subject relations where a student is not an object, but a subject of study on the basis of cooperation.

An example is the blended educational process in Lutsk Pedagogical College, where PBT is an organic component of it and largely ensure the effectiveness of the formation of professional and vital competence of students: the process of mastering language material and speech skills is carried out in the context of individual creative tasks; students (as a group or individually) creatively work on the implementation of a personally significant project task, in which everyone gets their share of work in accordance with personal interests, inclinations, talents; students themselves select the necessary material, including speech, plan the content of their activities and carry it out, achieving the desired result, which is demonstrated not by evaluation but by presentation of creative works, booklets, wall newspapers, conferences, exhibitions, films, albums, etc .; a teacher acts as an organizer, leader of the creative process, as a source of ideas and advice.

During the 2019-2020 academic year the interdisciplinary practice-oriented long- 
Comparative table of objectives of the PBT and educational process in Pedagogical College

\begin{tabular}{|c|c|}
\hline & $\begin{array}{c}\text { Objectives of the blanded educational process } \\
\text { on the } 3 \text { and } 4 \text { courses }\end{array}$ \\
\hline $\begin{array}{l}\text { Orientation of the educational process on those who are } \\
\text { udying, using the principle of "ego-factor" ("I-factor"), } \\
\text { e. personal orientation to goals, objectives, needs, interests, } \\
\text { otivation, life experience, individual characteristics } \\
\text { ad abilities of the personality. } \\
\text { Preparing the students for real-world activities by means } \\
\text { f practical actions regarding their emotional sphere and enhance } \\
\text { otivation of training due to more close connection between } \\
\text { te project ideas and real life. } \\
\text { Creative work on a chosen topic on the basis of independently } \\
\text { ollected, systematized and generalized information from } \\
\text { ifferent sources. } \\
\text { Independent thinking in identifying and solving the problems } \\
\text { sthe basis of knowledge from the different branches of science, } \\
\text { sing a variety of investigative and search methods and ways } \\
\text { f learning. } \\
\text { Ability to establish through the analysis the causal } \\
\text { lationships between the phenomena, to foresee the possible } \\
\text { onsequences of different variants of decisions, to plan } \\
\text { ad predict the results, to carry out actions to implement } \\
\text { ecisions, the receiving skills of using various forms } \\
\text { f organization of educational activities regarding the interaction } \\
\text { etween those who are studying, between themselves and with } \\
\text { achers who are becoming equal partners and consultants, } \\
\text { ahance the individual and collective responsibility to those who }\end{array}$ & $\begin{array}{l}\text { Further improvement of the professional, } \\
\text { ethodological, philosophical and public competences } \\
\text { the future specialist; the development of professional } \\
\text { ilities and ascent to the heights of creativity as } \\
\text { precondition for further independent professional } \\
\text { tivity; development of their intelligence. } \\
\text { Convert the motivation and the whole system of value } \\
\text { ientations; the formation of social values in connection with } \\
\text { ofessionalization; high educational level, high cognitive } \\
\text { otivation, the highest social activity and harmonious } \\
\text { mbination of intellectual and social maturity. } \\
\text { The leading role in cognitive activity plays a thinking } \\
\text { rmed a generalized picture of the world, installed } \\
\text { bsurface inter-relationships between different } \\
\text { sciplines. } \\
\text { Amplified expression properties such as determination, } \\
\text { dependence, initiative, persistence, self-mastery. } \\
\text { Fully or partially formed the following skills: } \\
\text { dderstand and internally take the aims and tasks of self- } \\
\text { ork; identify, organize and establish the sequence } \\
\text { execution; define and plan the sequence of actions } \\
\text { nethods and tools), required to perform a task; } \\
\text { ganize your work, mobilize available resources to } \\
\text { lve the given task; independently control their actions } \\
\text { cording to purpose; If there is a need, then adjust, } \\
\text { fine and regulate; evaluate the results of their self work } \\
\text { id determine its future prospects. }\end{array}$ \\
\hline
\end{tabular}

term project "Lina Kostenko. The poetess above an epoch" has been conducted by the instructors of philological disciplines of Lutsk Pedagogical CollegeIt involves the students of 3-4 courses of the department "Primary Education "with additional qualification" teacher of a foreign (English) language in primary school", who have received basic skills of project implementation earlier, as well as students of 1-2 courses, acquiring basic skills of project activities. The purpose of the project is to form in future education specialists' key competencies in general and the communicative competence (native and foreign) in particular; stimulating students to independent educational and cognitive activities; providing opportunities for self-education, selfdevelopment, self-expression of the individual in the process of search and local lore work.

The theoretical component of this project provides the implementation of curriculum requirements for academic disciplines: "Ukrainian language", "Ukrainian literature", "Modern Ukrainian language with a workshop", "Practical foreign language course", "Theoretical foreign language course", "History of Ukraine", "Informatics","Methods of teaching Ukrainian
language","Methods of teaching Foreign language".

The practical component of the project is aimed at the formation and improvement of future primary school teachers of complex professional skills and abilities: common: orthoepic, spelling, punctuation, lexical, grammatical, syntactic; formation of stable motivation to study native and foreign languages; development of skills in using reference books and other sources of information; communicative-speech: listening, reading, writing, speaking; UkrainianEnglish translation; adherence to a high culture of speech (Ukrainian and English); development of skills and abilities in all types of speech activity (listening, reading, speaking, writing) and in various spheres of communication (personal, public, educational); formation of communicative competence; methodical: to choose the appropriate forms and methods of teaching, didactic material; choose the best ways of learning; work with educational and methodical literature and other sources of information; analyze, synthesize, evaluate the received information; develop a plan and algorithm for project implementation; to make the analysis and self-analysis of activity in 
the project; constantly improve, increase their own level of academic achievement (self-development skills); to speak in front of an audience, to express one's opinion with arguments (communication skills); information and communication: work with information of different types; create and use efficient algorithms; use educational programs and information technology to teach junior high school students; to use informational, technical and methodical means of teaching in primary school; to implement interdisciplinary connections by means of informatics and modern information technologies.

The first (preparatory) stage of the project provides for the division of students into groups according totheirpreferences, students'development of theoretical material, discussion of key and thematic issues: Lina Kostenko: known or unknown? Is Lina Kostenko a symbol of Ukraine? What is the significance of Lina Kostenko's creative heritage for the whole world? What is interesting to know about Lina Kostenko to modern Ukrainians? In addition, the research algorithm and criteria for evaluating the project results are defined.

The purpose of the second stage is to research of selected topics, namely: search for information in scientific and methodological literature, media and Internet sources; survey of residents of Lutsk and the region; consultations with scientists, local historians, writers, publishers. The results of the study were discussed among groupmates and teachers.

The purpose of the third stage is to popularize the results of the project and its further expansion: presentation of the Ukrainian-English guidebook "Lina Kostenko. The poetess above an epoch"; the performance "Lina Kostenko's poems in translations in different languages" for students of the junior courses and pupils of senior classes; issue of the next copy of the newspaper "Bulletin of the College", dedicated to the anniversary of the writer. The results of the project are represented on the pages of the newsletter "Bulletin of the College".

The results of the project "Lina Kostenko. The poetess above an epoch" allow us to conclude that the PBT creates conditions for the organization of blended educational and developmental environment based on the enrichment of the curriculum content of native and foreign language education with personally meaningful content in which students are active subjects of individual professional development; assessment and self-assessment of ways of productive learning activities; assimilation of new knowledge by students on the basis of acquired subjective experience; structuring of educational material, providing opportunities for the use of information and communication technologies, the choice of content, type and form for individual tasks projects in accordance with the available subjective experience; formation of communicative (native and foreign language) competence of future teachers; active stimulation of students to independent educational and cognitive activities, providing opportunities for self-education, selfdevelopment, self-expression in the process of obtaining professional education.

The effectiveness of the project is confirmed by a significant improvement in the quality of training of primary school specialists, as evidenced by the results of tests, semester exams in academic disciplines, as well as improving the theoretical and practical level of teaching in primary school classes by 3-4 year students during pedagogical practice.

\section{Conclusions}

The ensurence of the effective personal and social students' development by using the PBT in terms of the blended educational process in pedagogical college is an important factor in the students' formation and development as future teachers, allows to build a complex of the professional orientation, educational creativity and socially significant competences of the personality of the future primary-school teacher. Blende educational process based on the PBT, becomes socio-educational system, in which the emerging sense of the national dignity, belonging to the world community, understanding of the professional choices on basement of the moral principles, individuality and creative identity of every student which teaches the basis of the lifecreativity and cooperation. The needs for the further developments we identify in improving pedagogical conditions of PBT implementation in pedagogical college, which will facilitate the changing of group and individual identities in perspective for the development of national education policy. 


\section{BIBLIOGRAPHY}

1. Aini, 2020 Aini, D.F.N. (2020). Pengembangan Pedoman EModul Berorientasi Student Active Learning Sebagai Pendukung Pembelajaran di Sekolah Dasar. Jurnal Pendidikan Dasar Nusantara, 5(2), 292-304

2. R. Bart, T. Olney, M. Nichols, Ch. Herodotou. (2020) Effective usage of learning analytics: what do practitioners want and where should distance learning institutions be going? Open Learning: The Journal of Open, Distance and e-Learning 35:2, pages 178-195.

3. Evtukh M.B., Serdiuk A.P. Social pedagogy: a course book. K.: MAUP, 2002. 232 p. refs.: p. 221-226.

4. Kolbrun Friðriksdóttir. (2019) The effect of tutor-specific and other motivational factors on student retention on Icelandic Online. Computer Assisted Language Learning 0:0, pages 1-22.

5. Graham, C.R. (2007). Blended learning systems: Definition, current trends and future directions. Handbook of blended learning: Global Perspective, local designs (pp. 3-21). San Francisco, CA: Pfeiffer Publishing.

6. Holloway \& Gouthro, 2020 Holloway, S.M., \& Gouthro, P.A. (2020). Using a multiliteracies approach to foster critical and creative pedagogies for adult learners. Journal of Adult and Continuing Education

7. Hrastinski, S., (2019). What do we mean by blended learning? Technology Trends Washington, 63(5), 564-569.

8. S. V. Ivanova, L. S. Pastukhova: The possibilities of using the project method in education and work with young people at the present time The Education and science journal 20(6): 29-49, July 2018

9. Zelenko, A.S. On the formation of semasiology in philosophical and psychological understanding: status and prospects: monograph. Lugansk: Alma Mater, 2005. 199 p.

\section{REFERENCES}

1. Law of Ukraine "On Education": Retrieved from https://zakon.rada.gov. ua/laws/show/2145-19

2. Profesiinyi standart za profesiiamy "Vchytel pochatkovykh klasiv zakladu zahalnoi serednoi osvity", "Vchytel z pochatkovoi osvity (z dyplomom molodshoho spetsialista)". [Professional standard for the professions "Primary school teacher of general secondary education", "Primary education teacher (with a diploma of junior specialist)"]. Retrieved from https://mon.gov.ua/ua/news/zatverdzheno-profstandart-vchitelya-pochatkovih-klasiv-vchitelya-zakladu-zagalnoyiserednoyi-osviti-i-vchitelya-z-pochatkovoyi-osviti [in Ukrainian].

3. Common European Framework Of Reference For Languages: Learning, Teaching, Assessment. Retrieved from https://rm.coe.int/16802fc1bf [in English].

4. Ananiev, B.G. Yzbrannye psykholohycheskye trudy [Selected psychological works] elib.gnpbu.ru Retrieved from http://elib.gnpbu.ru/text/ananyev_izbrannye-trudy_t1_1980/fs,1/ [in Ukrainian].

5. Dementievska, N., Morze, N. ICT for teacher's professional development. Retrieved from https://journal.iitta.gov. ua/index.php/itlt/article/view/293.

6. Dziuban, C., Graham, C.R., Moskal, P., Norberg, A., \& Sicilia, N., (2018). Blended learning: The new normal and emerging technologies. International Journal of Educational Technology in Higher Education, 15(3). Retrieved from https://educationaltechnologyjournal.springeropen.com/articles/10.1186/s41239-017-0087-5

7. Frank M. and Barzilai A. Project-Based Technology: Instructional Strategy for Developing Technological Literacy Retrieved from https://vtechworks.lib.vt.edu/ bitstream/handle/10919/8363/frank.pdf?sequence=1

8. Garrison, D.R., \& Kanuka, H. (2004). Blended learning: Uncovering its transformative potential in higher education. The Internet and Higher Education, 7(2), 95-105. Retrieved from http://dx.doi.org/10.1016/j.iheduc.2004.02.001.

9. Gulbahar,H.Beckett,TammySlater:Project-BasedLearningandTechnologyhttps://doi.org/10.1002/9781118784235. eelt0427.

10. Intel ${ }^{\circledR}$ Teach to the Future. (2003). Project-based classroom: Bridging the gap between education and technology. Retrieved from https://www.coursehero.com/file/29863594/11Design-Effective-Projpdf/.

11. Kosheleva, N.G. (2007). Using the method of projects in the construction course of "planning individual career" as the basis of student-oriented training of economists in universities. Problemy inzh.-ped. Osvity - Problems of eng.-ped. Education, 17, 267-273. Retrieved from https://refdb.ru/look/2585209.html.

12. Leontev, A.N. Deiatelnost. Soznanye. Lychnost [Activity. Consciousness. Personality]. Retrieved from http:// www.psy.msu.ru/people/leontiev/dsl/index.html.

13. Mahaye, N.E. The impact of COVID-19 pandemic on education: navigating forward the pedagogy of blended learning. Research online, 2020 - researchgate.net https://www.researchgate.net/profile/Mahaye-Ngogi-Emmanuel/ publication/ 340899662_Pandemic_on_South_African_Education_ Navigating_Forward_the_Pedagogy_of_Blended Learning/links/ 5ea315ae45851553faaa31ae/ The-Impact-of-COVID-19-Pandemic-on-South-African-EducationNavigating-Forward-the-Pedagogy-of-Blended-Learning.pdf.

14. Railsback, J. (2002). Project-based instruction: Creating excitement for learning. Portland, OR: Northwest Regional Educational Laboratory. Retrieved from https://educationnorthwest.org/sites/default/files/projectbased.pdf.

15. Thomas, J.W. (2000). A review of research on project-based learning. San Rafael, CA: Autodesk. Retrieved from http://www.bobpearlman.org/ BestPractices/PBL_Research.pdf

16. Yustina, Y., Syafii, W., Vebrianto, R. The Effects of Blended Learning and Project-Based Learning on Pre-Service Biology Teachers' Creative Thinking through Online Learning in the Covid-19 Pandemic Retrieved from https://journal. unnes.ac.id/nju/index.php/jpii/article/view/24706 


\section{А. В. БЛЯШЕВСЬКА}

кандидат педагогічних наук, дочент,

Комунальний вищчий навчальний заклад «Луиьький педагогічний коледж»

Волинської обласної ради, м. Луизьк, Україна

Електронна пошта: ablyashevsjka@lpk.ukr.education

https://orcid.org/0000-0003-3650-932X

\section{М. А. ФЕДОРЕЦЬ}

викладач іноземних мов,

Комунальний вищчий навчальний заклад «Луцьький педагогічний коледж»

Волинської обласної ради, м. Луизьк, Україна

Електронна пошта: mfedoretc@gmail.com

https://orcid.org/0000-0002-2990-4340

\section{ВПРОВАДЖЕННЯ ПРОЕКТНОЇ ТЕХНОЛОГІЇ У ПРОЦЕС ЗМІШЕНОГО НАВЧАННЯ ІНОЗЕМНОЇ МОВИ В ПЕДАГОГІЧНОМУ ЗАКЛАДІ ВИЩОЇ ОСВІТИ В УКРАЇНІ}

Сьогодні українське суспільство вимагає, щоб фахівець Нової української школи був готовий якісно виконувати свої професійні функції та повноцінно брати участь у всіх сферах життя. У цій статті висвітлено актуальні питання організації змішаного освітнього середовища в умовах пандемії у закладі вищої освіти України, а саме формування загальних та професійних компетенцій учителів початкових класів відповідно до нормативних актів: закону України "Про освіту", професійного стандарту для професій "Початкова школа шкільний учитель у закладі загальної середньої освіти "," Вчитель початкової освіти (з дипломом молодшого спеціаліста) ". Представлений аналіз впровадження проектної технології в освтній процес педагогічного коледжу як ефективного засобу особистого та соціального розвитку студентів під час занять 3 різних дисциплін, самостійної роботи студентів, а також під час пробної та переддипломної практики.

У статті подано огляд впровадження проектної технології в процес змішаного навчання іноземної мови для досягнення основних цілей вивчення мови майбутніми вчителями, що передбачає ефективне спілкування в усній та письмовій формах, використання мови як засобу міжкультурної комунікації, здатність використовувати мову як інструмент культурного діалогу в сучасному світі. Автори обгрунтовують дидактичний потенціал інтерактивних методів навчання, зокрема проектної технології, як складової системи формування комунікативної компетентності у процесі вивчення англійської мови.

Проведено аналіз та узагальнення досвіду викладачів іноземних мов у Луцькому педагогічному коледжі, беручи за приклад процес організації навчального процесу, що реалізує міждисциплінарний довгостроковий практико-орієнтований проект "Ліна Костенко. Поетеса над епохою", до якого залучені студенти - майбутні вчителі початкових класів 3 додатковою кваліфікацією «Вчитель англійської мови в початковій школі». У цій статті доведено ефективність проектної технології в системі формування загальної та професійної компетентностей, а також комунікативної компетентності студентів педагогічних ЗВО України.

Ключові слова: технологія основана на проекті, інноваційні технології, особистий та соціальний розвиток, змішане навчання, майбутній вчитель початкових класів, педагогічні заклади вищої освіти. 